(c) American Dairy Science Association, 2007.

\title{
Genetic Parameters for Yield Traits of Cows Treated or Not Treated with Bovine Somatotropin ${ }^{1}$
}

\author{
A. Al-Seaf, ${ }^{\star}$ J. F. Keown, ${ }^{* 2}$ and L. D. Van Vleck ${ }^{\star} \dagger$ \\ ${ }^{*}$ Department of Animal Science, University of Nebraska, Lincoln, 68583-0908 \\ †Roman L. Hruska U.S. Meat Animal Research Center, ARS, USDA, Lincoln, NE 68583-0908
}

\begin{abstract}
The objective of this study was to estimate genetic correlations between yield traits of cows treated with bovine somatotropin (bST) and the same yield traits of untreated cows. Lactation records from registered Holstein cows were divided by parity into 3 data sets: 1,2 , and 3 through 5 . Approximately $10 \%$ of the records in each data set were from cows treated with bST. The numbers of records of treated and untreated cows in the data sets were 4,337 and 48,$765 ; 3,730$ and 37,796 ; and 3,645 and 33,957. Two-trait animal models (records for cows treated or not treated) were used to estimate genetic parameters for milk production traits and somatic cell score (SCS). Estimates of heritability for milk yield for records of treated and untreated cows for the 3 data sets were $0.13,0.16$, and 0.09 , and $0.18,0.18$, and 0.14 , respectively, with estimates of repeatability of 0.50 and 0.41 for data set 3. Estimates of heritability for fat yield for records of treated and untreated cows were $0.31,0.16$, and 0.12 , and $0.27,0.21$, and 0.16 . Estimates of repeatability were 0.50 and 0.43 for data set 3 . Heritability estimates for protein yield for records of treated and untreated cows were $0.13,0.17$, and 0.12 , and $0.20,0.23$, and 0.16 , with estimates of repeatability of 0.52 and 0.47. Estimates of heritability for SCS for treated and untreated cows were $0.08,0.15$, and 0.13 , and $0.11,0.13$, and 0.13 with repeatability estimates of 0.52 and 0.45 . Estimates of genetic correlations between milk yields with and without bST treatment in lactations 1, 2, and 3 to 5 were all 0.99. Estimates of genetic correlations for fat and protein yields were 0.96 for all data sets. Estimates for SCS were 0.99. Estimates of genetic correlations between records of treated and untreated cows were large enough to conclude that records of treated and untreated cows could be considered to be one trait, with treatment as a fixed effect to account for differences in means.
\end{abstract}

Received November 15, 2005.

Accepted August 9, 2006.

${ }^{1}$ Published as paper No. 15023, Journal Ser., Nebraska Agric. Res. Div., Univ. of Nebraska, Lincoln 68583-0908.

${ }^{2}$ Corresponding author: jkeown1@unl.edu
Key words: bovine somatotropin, genetic parameters, milk yield, somatic cell score

\section{INTRODUCTION}

Bovine somatotropin (bST) is widely accepted and used as a management tool to enhance dairy cow productivity. Of the nearly 9 million dairy cows in the United States, approximately one-third are in herds that use bST (Monsanto, 2006). Several studies have documented the effects of bST. If dairy cows are injected biweekly with bST during lactation, milk production can increase by 10 to $15 \%$ (Bauman et al., 1985). Similar results were reported in 15 commercial dairy herds given bST, with responses ranging from 11 to $29 \%$ for milk yield (Thomas et al., 1991). Peel and Bauman (1987) reported that milk yield slowly increases the first few days after bST treatment, with maximum yield at about the sixth day after administration. Jordan et al. (1991) reported that milk and protein yields increased by 18.8 and $3.3 \%$, respectively, for high-producing cows, with no effect on somatic cell score (SCS). AlJumaah (2001) showed that SCS were slightly less in bST herds. Tsuruta et al. (2000) reported no significant difference for SCS between records of cows with or without bST. Hartnell et al. (1991) found significant effects for bST for milk yield traits, but not for SCS or for percentages of fat and protein.

Injection of bST not only increases milk production, but also increases persistency of production. Thus, the economically optimal calving interval may be increased with use of bST (Bauman, 1992). Many studies (e.g., Hansen et al., 1994; Etherton and Bauman, 1998; Bauman et al., 1999) have demonstrated that the most important factor determining the magnitude of the effect of bST treatment is herd management. Burton et al. (1990) reported that bST can enhance milk yields without an apparent effect on mammary gland or general cow health. Collier et al. (2001), in a study on the effect of using bST on the health of cows in commercial dairy cattle herds that were chosen randomly from different regions of the United States, showed that health problems in cows treated by bST were the same as 
Table 1. Numbers of records, herds, sires and dams of cows, and herd-year-month (HYM) classes for lactations 1, 2, and 3 and later for cows treated (Yes) or untreated (No) with bST

\begin{tabular}{|c|c|c|c|c|c|c|}
\hline \multirow[b]{2}{*}{ Item } & \multicolumn{2}{|c|}{ Lactation 1} & \multicolumn{2}{|c|}{ Lactation 2} & \multicolumn{2}{|c|}{ Lactation $3+$} \\
\hline & Yes & No & Yes & No & Yes & No \\
\hline Records & 4,337 & 48,756 & 3,730 & 37,796 & 3,654 & 33,957 \\
\hline Herds & 152 & 499 & 166 & 495 & 175 & 497 \\
\hline Sires & 1,331 & 6,639 & 1,252 & 5,817 & 1,329 & 5,743 \\
\hline Dams & 3,807 & 39,755 & 3,225 & 31,474 & 3,092 & 28,158 \\
\hline HYM & 1,397 & 13,338 & 1,458 & 13,214 & 1,586 & 14,168 \\
\hline
\end{tabular}

health problems normally found in commercial dairy herds.

Weigel et al. (1998) estimated heritability and repeatability for milk yield to be 0.20 and 0.42 for records of treated cows and obtained similar estimates of 0.21 and 0.42 for records of untreated cows. Al-Jumaah (2001) obtained estimates of heritability for milk, fat, and protein yields with $b S T$ of $0.18,0.16$, and 0.16 , respectively, with estimates of repeatability of $0.43,0.40$, and 0.40 and corresponding estimates for yields without bST of $0.13,0.16$, and 0.16 , with estimates of repeatability of $0.39,0.40$, and 0.40 . Tsuruta et al. (2000) reported estimates of heritability of 0.19 and repeatability of 0.39 for milk yield for cows treated with bST.

The Food and Drug Administration approved the use of bST on dairy cows in 1993. Since then, records from cows treated with bST have accumulated at Dairy Records Processing Centers. The objective of this study was to examine the possibility of a genotype $\times$ environmental interaction by estimating genetic correlations for yield traits and SCS between a trait when cows were treated with bST and the same trait when cows were not treated with bST. These correlations were estimated separately for first, second, and third through fifth lactations.

\section{MATERIALS AND METHODS}

Data obtained from the Dairy Records Processing Center in Raleigh, North Carolina, were from 16 different states for lactation yields (milk, fat, and protein) and SCS. For pedigree data to be as accurate as possible, only records of cows with valid registration numbers for registered Holstein cows were included in this study. Lactation yields were preadjusted to a 305-d, twice-daily milking, and mature equivalent basis. The SCS is a logarithmic transformation (base 2) of SCC (see Da et al., 1992). After editing, records for registered cows were divided into 3 data subsets by lactation number: lactation 1 , lactation 2 , and lactations 3 through 5 . The 3 data sets contained 4,337 and 48,$765 ; 3,730$ and 37,796; and 3,654 and 33,957 records, respectively, for bST-treated and untreated cows, as shown in Table
1. The numbers of bST records are relatively small because of the emphasis on obtaining as accurate pedigree identification as possible. As more data accumulate, results from this study should be pooled with later studies. A pilot project such as this may provide a base on which to build. The percentages of records of cows treated with bST were 8.8, 9.8, and $10.7 \%$ for lactation 1 , lactation 2 , and lactations 3 through 5 , respectively. Records were from 651, 661, and 672 herds, respectively. For a record to be considered treated with bST, the cow had to be reported to be injected with bST 3 or more times. Records of cows treated, but treated less than 3 times during a lactation, were not used in the study. Only records of cows with sires with known registration numbers having at least 5 daughters in a data set were used. For data set 3 , about $25 \%$ of cows with bST records also had untreated records, $15 \%$ with bST records had more than one bST record, and about $40 \%$ with untreated records had more than one untreated record, which allowed estimation of repeatability within treatment groups and a permanent environmental correlation between treatment groups.

A 2-trait animal model was used to estimate variance and covariance components and genetic parameters for yield traits and for SCS. Records from cows with or without bST treatment were considered to be 2 different traits. In matrix form, the model was

$$
\left[\begin{array}{l}
\mathbf{y}_{\mathrm{i}} \\
\mathbf{y}_{\mathrm{j}}
\end{array}\right]=\left[\begin{array}{cc}
\mathbf{X}_{\mathrm{i}} & \mathbf{0} \\
\mathbf{0} & \mathbf{X}_{\mathrm{j}}
\end{array}\right]\left[\begin{array}{c}
\boldsymbol{\beta}_{\mathrm{i}} \\
\boldsymbol{\beta}_{\mathrm{j}}
\end{array}\right]+\left[\begin{array}{cc}
\mathbf{Z}_{\mathrm{i}} & \mathbf{0} \\
\mathbf{0} & \mathbf{Z}_{\mathrm{j}}
\end{array}\right]\left[\begin{array}{c}
\mathbf{a}_{\mathrm{i}} \\
\mathbf{a}_{\mathrm{j}}
\end{array}\right]+\left[\begin{array}{cc}
\mathbf{W}_{\mathrm{i}} & \mathbf{0} \\
\mathbf{0} & \mathbf{W}_{\mathrm{j}}
\end{array}\right]\left[\begin{array}{c}
\mathbf{p}_{\mathrm{i}} \\
\mathbf{p}_{\mathrm{j}}
\end{array}\right]+\left[\begin{array}{c}
\mathbf{e}_{\mathrm{i}} \\
\mathbf{e}_{\mathrm{j}}
\end{array}\right]
$$

(for lactations 1 and 2 the permanent environmental effects are not in the model), where $\mathbf{y}_{\mathrm{i}}$ and $\mathbf{y}_{\mathrm{j}}$ are vectors of records of cows for trait $i$ (treated) and trait $j$ (untreated); $\boldsymbol{\beta}_{\mathrm{i}}$ and $\boldsymbol{\beta}_{\mathrm{j}}$ are vectors of fixed effects (contemporary groups, herd-year-month of calving) for traits $i$ and $\mathrm{j} ; \mathbf{a}_{\mathrm{i}}$ and $\mathbf{a}_{\mathrm{j}}$ are vectors of random additive genetic effects for animals for traits $\mathrm{i}$ and $\mathrm{j} ; \mathbf{p}_{\mathrm{i}}$ and $\mathbf{p}_{\mathrm{j}}$ are vectors of random permanent environmental effects for cows for traits $i$ and $j$ for analyses of lactations 3 through $5 ; \mathbf{e}_{i}$ and $\mathbf{e}_{\mathrm{j}}$ are vectors of random residual effects for traits $\mathrm{i}$ and $\mathrm{j} ; \mathbf{X}_{\mathrm{i}}, \mathbf{Z}_{\mathrm{i}}$, and $\mathbf{W}_{\mathrm{i}}$ are known design matrices for 
Table 2. Means (305-d, mature equivalent, $2 \times$ ) and standard deviations unadjusted for contemporary effects for milk, fat, and protein yields (kg) and SCS for lactations 1, 2, and 3 and later for cows treated (Yes) or untreated (No) with bST

\begin{tabular}{|c|c|c|c|c|c|c|c|c|c|c|c|c|}
\hline \multirow[b]{2}{*}{ Item } & \multicolumn{4}{|c|}{ Lactation 1} & \multicolumn{4}{|c|}{ Lactation 2} & \multicolumn{4}{|c|}{ Lactation $3+$} \\
\hline & Mean & $\mathrm{SD}$ & Mean & $\mathrm{SD}$ & Mean & $\mathrm{SD}$ & Mean & $\mathrm{SD}$ & Mean & $\mathrm{SD}$ & Mean & $\mathrm{SD}$ \\
\hline Milk & 11,290 & 2,000 & 10,290 & 1,880 & 11,440 & 2,230 & 10,490 & 2,100 & 10,780 & 2,180 & 10,050 & 2,060 \\
\hline Fat & 411 & 77 & 366 & 76 & 413 & 86 & 373 & 84 & 393 & 93 & 358 & 85 \\
\hline Protein & 345 & 58 & 318 & 54 & 354 & 64 & 325 & 61 & 334 & 64 & 312 & 61 \\
\hline SCS & 1.2 & 0.6 & 1.6 & 0.7 & 1.5 & 0.6 & 1.5 & 0.6 & 1.6 & 0.7 & 1.6 & 0.7 \\
\hline
\end{tabular}

trait i; and $\mathbf{X}_{\mathrm{j}}, \mathbf{Z}_{\mathrm{j}}$, and $\mathbf{W}_{\mathrm{j}}$ are known design matrices for trait j. For

$$
\mathbf{a}=\left(\begin{array}{l}
\mathbf{a}_{\mathrm{i}} \\
\mathbf{a}_{\mathrm{j}}
\end{array}\right), \mathbf{p}=\left(\begin{array}{l}
\mathbf{p}_{\mathrm{i}} \\
\mathbf{p}_{\mathrm{j}}
\end{array}\right) \text {, and e }=\left(\begin{array}{l}
\mathbf{e}_{\mathrm{i}} \\
\mathbf{e}_{\mathrm{j}}
\end{array}\right),
$$

the first and second moments from the means for first or second lactations for animals with one record each were assumed to be

$$
\mathrm{E}\left[\begin{array}{l}
\mathrm{a} \\
\mathrm{e}
\end{array}\right]=\left[\begin{array}{l}
0 \\
0
\end{array}\right] \text { and } \operatorname{Var}\left[\begin{array}{l}
\mathrm{a} \\
\mathrm{e}
\end{array}\right]=\left[\begin{array}{cc}
G_{0} \otimes \mathrm{A} & 0 \\
0 & \mathrm{R}
\end{array}\right] \text {. }
$$

The moments for data set 3 were assumed to be

$$
\mathrm{E}\left[\begin{array}{c}
\mathrm{a} \\
\mathrm{pe} \\
\mathrm{e}
\end{array}\right]=\left[\begin{array}{c}
0 \\
\mathrm{pe} \\
0
\end{array}\right] \text { and } \operatorname{Var}\left[\begin{array}{c}
\mathrm{a} \\
\mathrm{pe} \\
\mathrm{e}
\end{array}\right]=\left[\begin{array}{ccc}
\mathrm{G}_{0} \otimes \mathrm{A} & 0 & 0 \\
0 & \mathrm{P}_{0} \otimes \mathrm{I}_{\mathrm{P}} & 0 \\
0 & 0 & \mathrm{R}
\end{array}\right] \text {, }
$$

where $\otimes$ is the right direct product operator; $\mathrm{A}$ is the matrix of additive genetic relationships among animals including foundation animals without records; $G_{0}$ is the additive genetic variance-covariance matrix; $\mathrm{P}_{0}$ is the permanent environmental variance-covariance matrix; $\mathrm{I}_{\mathrm{P}}$ is an identity matrix with order equal to the total number of cows with records; $\sigma_{\mathrm{a}_{\mathrm{i}}}^{2}$ and $\sigma_{\mathrm{a}_{\mathrm{j}}}^{2}$ are the additive genetic variances for traits $\mathrm{i}$ and $\mathrm{j} ; \sigma_{\mathrm{a}_{\mathrm{i}} \mathrm{a}_{\mathrm{j}}}$ is the genetic covariance between traits $\mathrm{i}$ and $\mathrm{j} ; \sigma_{\mathrm{pe}_{\mathrm{i}}}^{2}$ and $\sigma_{\mathrm{pe}_{\mathrm{j}}}^{2}$ are the permanent environmental variances for traits $i$ and $j$; $\sigma_{\mathrm{pe}_{\mathrm{i}} \mathrm{pe}_{\mathrm{j}}}$ is the permanent environmental covariance between traits $i$ and $j$, which can be estimated only from records of cows with both treated and untreated lactations; $\mathrm{R}$ is the matrix of residual variances; $\sigma_{\mathrm{e}_{\mathrm{i}}}^{2}$ and $\sigma_{\mathrm{e}_{\mathrm{j}}}^{2}$ are the residual variances for traits $\mathrm{i}$ and $\mathrm{j}$; and $\mathrm{I}_{\mathrm{n}_{\mathrm{i}}}$ and $I_{n_{j}}$ are identity matrixes with orders equal to the number of records for traits $i$ and $j$.

The means for each trait before analyses for records of cows with and without bST treatment in different lactations are shown in Table 2. For the 3 data sets, average differences $(\mathrm{kg})$ were $1,000,950$, and 730 for milk; 45, 40, and 35 for fat; and 27, 29, and 22 for protein, respectively. Differences between treated and untreated cows for SCS in the 3 data sets were -0.4 , 0.0 , and 0.0 , respectively.

Variance components and fixed effects were estimated using a derivative-free REML algorithm (Graser et al., 1987) with the programs developed by Boldman et al. (1995). Local convergence was considered to be met if the variance of the $-2 \log$ likelihoods in the simplex was less than $1 \times 10^{-6}$. After first convergence, restarts were made to find global convergence, with convergence declared when the values of -2 log likelihood did not change to the second decimal.

\section{RESULTS AND DISCUSSION}

Estimates from the 2-trait (records of treated and untreated cows) analyses are shown in Tables 3 through 6. Estimates of correlations are in Table 7.

Estimates of heritability, repeatability, and variance components for milk yield are listed in Table 3. For milk yield for records of cows with bST, the estimates of heritability for lactations 1,2 , and later were 0.13 , 0.16 , and 0.09 , respectively, and were $0.18,0.18$, and 0.14 for records of untreated cows. Estimates of repeatability for lactations 3 and later were 0.50 and 0.41 for records of treated and untreated cows. Weigel et al. (1998) estimated heritability and repeatability for milk yield to be 0.20 and 0.42 for records of treated cows and to be 0.21 and 0.42 for records of untreated cows. AlJumaah (2001) obtained estimates of heritability of 0.18 and of repeatability of 0.43 for milk yield with bST and of 0.13 and 0.39 for untreated cows. Tsuruta et al. (2000) reported estimates of heritability of 0.19 and repeatability of 0.39 for milk yield for cows treated with bST.

Estimates of variance components, heritability, and repeatability for fat yield for lactations 1,2 , and later are shown in Table 4. Estimates of heritability were $0.31,0.16$, and 0.12 with bST treatment and $0.27,0.21$, and 0.16 without bST, respectively. Repeatability estimates were 0.50 and 0.43 . Tsuruta et al. (2000) reported 
Table 3. Estimates (Est) of variance components, heritability (with SE), and repeatability for lactations 1, 2, and 3 and later for 305-d milk yield $(\mathrm{kg} / 100)$ for cows treated (Yes) or untreated (No) with bST

\begin{tabular}{|c|c|c|c|c|c|c|c|c|c|c|c|c|}
\hline \multirow[b]{3}{*}{ Parameter $^{1}$} & \multicolumn{4}{|c|}{ Lactation 1} & \multicolumn{4}{|c|}{ Lactation 2} & \multicolumn{4}{|c|}{ Lactation $3+$} \\
\hline & \multicolumn{2}{|c|}{ Yes } & \multicolumn{2}{|c|}{ No } & \multicolumn{2}{|c|}{ Yes } & \multicolumn{2}{|c|}{ No } & \multicolumn{2}{|c|}{ Yes } & \multicolumn{2}{|c|}{ No } \\
\hline & Est & $\mathrm{SE}$ & Est & $\mathrm{SE}$ & Est & SE & Est & $\mathrm{SE}$ & Est & SE & Est & SE \\
\hline$\sigma_{\mathrm{a}}^{2}$ & 65.9 & 26.1 & 85.8 & 7.3 & 118.8 & 52.4 & 120.2 & 12.2 & 66.4 & 39.1 & 89.9 & 9.6 \\
\hline$\sigma_{\mathrm{pe}}^{2}$ & - & - & - & 一 & - & - & 一 & - & 273.2 & 54.5 & 191.9 & 10.9 \\
\hline$\sigma_{\mathrm{e}}^{2}$ & 453.5 & 27.8 & 394.4 & 6.8 & 607.7 & 52.5 & 535.5 & 11.5 & 360.7 & 36.4 & 368.9 & 6.3 \\
\hline$\sigma_{\mathrm{p}}^{2}$ & 519.5 & 13.5 & 480.3 & 3.7 & 726.5 & 21.8 & 655.7 & 6.1 & 700.4 & 19.9 & 650.8 & 5.4 \\
\hline$h^{2}$ & 0.13 & 0.05 & 0.18 & 0.01 & 0.16 & 0.07 & 0.18 & 0.02 & 0.09 & 0.05 & 0.14 & 0.01 \\
\hline $\mathrm{r}$ & - & - & - & - & - & - & - & - & 0.50 & - & 0.41 & - \\
\hline
\end{tabular}

${ }^{1}$ Additive genetic variance $\left(\sigma_{\mathrm{a}}^{2}\right)$, residual environmental variance $\left(\sigma_{\mathrm{e}}^{2}\right)$, total phenotypic variance $\left(\sigma_{\mathrm{p}}^{2}\right)$, permanent environmental variance $\left(\sigma_{\text {pe }}^{2}\right)$, heritability $\left(\mathrm{h}^{2}\right)$, and repeatability $(\mathrm{r})$.

an estimate of heritability for fat yield of treated cows to be 0.29 using a test-day model. Al-Jumaah (2001) obtained estimates of heritability and repeatability of 0.16 and 0.43 for records of treated cows and of 0.16 and 0.40 for untreated cows.

Estimates of variance components, heritability, and repeatability for protein yield for lactations 1, 2, and later are shown in Table 5. Heritability estimates were $0.13,0.17$, and 0.12 for records of cows with bST, with a repeatability estimate for later lactations of 0.52 . For untreated cows, the estimates of heritability were 0.20 , 0.23 , and 0.16 , respectively, and the estimate of repeatability was 0.47 . Estimates of heritability and repeatability agree with estimates by Dematawewa and Berger (1998), Tsuruta et al. (2000), and Al-Jumaah (2001).

Estimates of variance components, heritability, and repeatability for SCS for lactations 1, 2, and later are listed in Table 6. Heritability estimates were $0.08,0.15$, and 0.13 , respectively, with an estimate of repeatability of 0.52 . For untreated cows, the estimates of heritability were $0.11,0.13$, and 0.13 , respectively, with an estimate of repeatability of 0.45 . Tsuruta et al. (2000) reported estimates of heritability of 0.03 to 0.09 with different test-day models used to estimate genetic parameters. Al-Jumaah (2001) obtained estimates of heritability and repeatability of 0.22 and 0.40 for records of treated cows. For untreated cows, his estimates were 0.21 and 0.34 .

Overall, estimates of heritability for yields in later lactations were a little less than for lactations 1 and 2; this could be a result of selection on lactations 1 and 2 , which could reduce the range of differences of later records. If computationally feasible, future research on the effect of bST on estimates of parameters for different parities could use 6 -trait models ( 2 treatments by 3 parity groups) to reduce possible biases in estimates for later parities attributable to culling. The standard errors of estimates, however, are large enough to suggest that differences may be due to sampling.

Misidentification of sires of cows and dams of cows may also affect estimates of heritability. If more treated

Table 4. Estimates (Est) of variance components, heritability, repeatability (with SE) for lactations 1, 2, and 3 and later for 305-d fat yield (kg/10) for cows treated (Yes) or untreated (No) with bST

\begin{tabular}{|c|c|c|c|c|c|c|c|c|c|c|c|c|}
\hline \multirow[b]{3}{*}{ Parameter $^{1}$} & \multicolumn{4}{|c|}{ Lactation 1} & \multicolumn{4}{|c|}{ Lactation 2} & \multicolumn{4}{|c|}{ Lactation $3+$} \\
\hline & \multicolumn{2}{|c|}{ Yes } & \multicolumn{2}{|c|}{ No } & \multicolumn{2}{|c|}{ Yes } & \multicolumn{2}{|c|}{ No } & \multicolumn{2}{|c|}{ Yes } & \multicolumn{2}{|c|}{ No } \\
\hline & Est & $\mathrm{SE}$ & Est & $\mathrm{SE}$ & Est & $\mathrm{SE}$ & Est & $\mathrm{SE}$ & Est & SE & Est & $\mathrm{SE}$ \\
\hline$\sigma_{\mathrm{a}}^{2}$ & 23.5 & 4.5 & 17.7 & 1.2 & 17.2 & 8.3 & 19.3 & 4.6 & 12.8 & 7.1 & 15.9 & 1.6 \\
\hline$\sigma_{\mathrm{pe}}^{2}$ & - & - & - & - & - & - & - & - & 40.9 & 9.2 & 27.3 & 1.8 \\
\hline$\sigma_{\mathrm{e}}^{2}$ & 51.8 & 4.6 & 48.8 & 1.1 & 87.9 & 8.3 & 73.4 & 4.7 & 55.6 & 5.8 & 54.9 & 0.9 \\
\hline$\sigma_{\mathrm{p}}^{2}$ & 75.3 & 2.1 & 66.5 & 0.5 & 105.1 & 3.4 & 92.7 & 1.9 & 109.4 & 3.3 & 98.2 & 0.8 \\
\hline$h^{2}$ & 0.31 & 0.06 & 0.27 & 0.02 & 0.16 & 0.08 & 0.21 & 0.06 & 0.12 & 0.06 & 0.16 & 0.01 \\
\hline $\mathrm{r}$ & - & - & - & - & - & - & - & - & 0.50 & - & 0.43 & 一 \\
\hline
\end{tabular}

\footnotetext{
${ }^{1}$ Additive genetic variance $\left(\sigma_{\mathrm{a}}^{2}\right)$, residual environmental variance $\left(\sigma_{\mathrm{e}}^{2}\right)$, total phenotypic variance $\left(\sigma_{\mathrm{p}}^{2}\right)$, perma-
} nent environmental variance $\left(\sigma_{\text {pe }}^{2}\right)$, heritability $\left(\mathrm{h}^{2}\right)$, and repeatability $(\mathrm{r})$. 
Table 5. Estimates (Est) of variance components, heritability, repeatability (with SE) for lactations 1,2 and 3 and later for 305-d protein yield (kg/10) for cows treated (Yes) or untreated (No) with bST

\begin{tabular}{|c|c|c|c|c|c|c|c|c|c|c|c|c|}
\hline \multirow[b]{3}{*}{ Parameter $^{1}$} & \multicolumn{4}{|c|}{ Lactation 1} & \multicolumn{4}{|c|}{ Lactation 2} & \multicolumn{4}{|c|}{ Lactation $3+$} \\
\hline & \multicolumn{2}{|c|}{ Yes } & \multicolumn{2}{|c|}{ No } & \multicolumn{2}{|c|}{ Yes } & \multicolumn{2}{|c|}{ No } & \multicolumn{2}{|c|}{ Yes } & \multicolumn{2}{|c|}{ No } \\
\hline & Est & $\mathrm{SE}$ & Est & $\mathrm{SE}$ & Est & $\mathrm{SE}$ & Est & $\mathrm{SE}$ & Est & $\mathrm{SE}$ & Est & $\mathrm{SE}$ \\
\hline$\sigma_{\mathrm{a}}^{2}$ & 5.3 & 2.3 & 7.5 & 0.6 & 10.0 & 4.6 & 12.2 & 1.1 & 7.1 & 3.9 & 8.6 & 0.9 \\
\hline$\sigma_{\mathrm{pe}}^{2}$ & - & - & - & - & - & - & - & - & 24.9 & 5.1 & 17.3 & 1.0 \\
\hline$\sigma_{\mathrm{e}}^{2}$ & 35.8 & 2.4 & 30.4 & 0.5 & 48.8 & 4.7 & 41.5 & 1.1 & 28.3 & 3.2 & 29.3 & 0.5 \\
\hline$\sigma_{\mathrm{p}}^{2}$ & 41.1 & 1.1 & 38.0 & 0.3 & 58.8 & 1.9 & 53.7 & 0.5 & 60.4 & 1.8 & 55.2 & 0.6 \\
\hline $\mathrm{h}^{2}$ & 0.13 & 0.06 & 0.20 & 0.02 & 0.17 & 0.08 & 0.23 & 0.02 & 0.12 & 0.06 & 0.16 & 0.01 \\
\hline $\mathrm{r}$ & - & - & - & - & - & - & - & - & 0.52 & - & 0.47 & - \\
\hline
\end{tabular}

${ }^{1}$ Additive genetic variance $\left(\sigma_{\mathrm{a}}^{2}\right)$, residual environmental variance $\left(\sigma_{\mathrm{e}}^{2}\right)$, total phenotypic variance $\left(\sigma_{\mathrm{p}}^{2}\right)$, permanent environmental variance $\left(\sigma_{\text {pe }}^{2}\right)$, heritability $\left(\mathrm{h}^{2}\right)$, and repeatability $(\mathrm{r})$.

cows are misidentified, estimates of heritability would be expected to be smaller (Israel and Weller, 2000).

In this study, for 8 of the 9 analyses of yield traits, estimates of heritability were less for treated than for untreated records, as shown in Tables 3,4 , and 5. The estimates were more similar for treated and untreated cows for SCS (Table 6). Estimates of phenotypic and permanent environmental variances were greater for records of cows receiving bST. Overall, estimates of phenotypic variance for milk, fat, and protein yields and SCS for all data sets were greater for records of cows treated with bST than for records of cows untreated with bST. In contrast, estimates of genetic variance for milk, fat, and protein yields were slightly greater for records of cows untreated with bST. The results in this study were in the range of those reported by Al-Jumaah (2001) and Albuquerque et al. (1996). Whether the differences in estimates of genetic and phenotypic variances for treated and untreated cows and for different parity classes are great enough to influence rankings for genetic evaluation should be the object of further research.
Estimates of genetic and environmental correlations between treated and untreated cows for the 3 yield traits and SCS are shown in Table 7. The estimates of genetic correlations between milk yields with and without bST for the 3 data sets were $0.99,0.99$, and 0.99 , with an estimate of permanent environmental correlation of 0.99 for data set 3. Estimates were slightly less for genetic correlations between fat yields of treated and untreated cows for all data sets $(0.96,0.96$, and $0.96)$, as was the estimate of permanent environmental correlation of 0.94 for data set 3 . Estimates for protein yield were the same as for fat yield. Estimates of genetic correlations between SCS of treated and untreated cows for all data sets also were near unity $(0.99,0.99$, and 0.99 ) but the estimate of the permanent environmental correlation for data set 3 was smaller (0.75). Estimates of genetic correlations were large enough to support the conclusion of considering a single-trait analysis for records of treated and untreated cows with bST treatment as a fixed effect.

Estimates of breeding values for cows and sires could be biased if bST is not used uniformly within a herd,

Table 6. Estimates (Est) of variance components, heritability, repeatability (with SE) for lactations 1, 2, and 3 and later for SCS for cows treated (Yes) or untreated (No) with bST

\begin{tabular}{|c|c|c|c|c|c|c|c|c|c|c|c|c|}
\hline \multirow[b]{3}{*}{ Parameter $^{1}$} & \multicolumn{4}{|c|}{ Lactation 1} & \multicolumn{4}{|c|}{ Lactation 2} & \multicolumn{4}{|c|}{ Lactation $3+$} \\
\hline & \multicolumn{2}{|c|}{ Yes } & \multicolumn{2}{|c|}{ No } & \multicolumn{2}{|c|}{ Yes } & \multicolumn{2}{|c|}{ No } & \multicolumn{2}{|c|}{ Yes } & \multicolumn{2}{|c|}{ No } \\
\hline & Est & $\mathrm{SE}$ & Est & $\mathrm{SE}$ & Est & $\mathrm{SE}$ & Est & $\mathrm{SE}$ & Est & $\mathrm{SE}$ & Est & $\mathrm{SE}$ \\
\hline$\sigma_{\mathrm{a}}^{2}$ & 0.06 & 0.03 & 0.07 & 0.01 & 0.12 & 0.05 & 0.09 & 0.01 & 0.14 & 0.06 & 0.13 & 0.01 \\
\hline$\sigma_{\mathrm{pe}}^{2}$ & - & - & - & - & - & - & - & - & 0.44 & 0.09 & 0.32 & 0.01 \\
\hline$\sigma_{\mathrm{e}}^{2}$ & 0.69 & 0.04 & 0.62 & 0.01 & 0.70 & 0.05 & 0.63 & 0.00 & 0.53 & 0.05 & 0.54 & 0.01 \\
\hline$\sigma_{\mathrm{p}}^{2}$ & 0.75 & 0.01 & 0.69 & 0.01 & 0.82 & 0.02 & 0.72 & 0.00 & 1.11 & 0.03 & 1.00 & 0.01 \\
\hline $\mathrm{h}^{2}$ & 0.08 & 0.05 & 0.11 & 0.02 & 0.15 & 0.07 & 0.13 & 0.02 & 0.13 & 0.05 & 0.13 & 0.01 \\
\hline $\mathrm{r}$ & - & - & - & - & - & - & - & - & 0.52 & - & 0.45 & - \\
\hline
\end{tabular}

${ }^{1}$ Additive genetic variance $\left(\sigma_{\mathrm{a}}^{2}\right)$, residual environmental variance $\left(\sigma_{\mathrm{e}}^{2}\right)$, total phenotypic variance $\left(\sigma_{\mathrm{p}}^{2}\right)$, permanent environmental variance $\left(\sigma_{\text {pe }}^{2}\right)$, heritability $\left(\mathrm{h}^{2}\right)$, and repeatability $(\mathrm{r})$. 
Table 7. Estimates of genetic $(\mathrm{G})$ and permanent environmental (PE) correlations for milk, fat, and protein yields and SCS with and without bST treatment as 2 different traits for lactations 1, 2, and 3 up to 5

\begin{tabular}{|c|c|c|c|c|c|c|c|c|}
\hline \multirow[b]{2}{*}{ Lactation } & \multicolumn{2}{|c|}{ Milk } & \multicolumn{2}{|c|}{ Fat } & \multicolumn{2}{|c|}{ Protein } & \multicolumn{2}{|c|}{ SCS } \\
\hline & G & $\mathrm{PE}$ & G & $\mathrm{PE}$ & G & $\mathrm{PE}$ & G & $\mathrm{PE}$ \\
\hline 1 & 0.99 & - & 0.96 & - & 0.96 & - & 0.99 & - \\
\hline 2 & 0.99 & - & 0.96 & - & 0.96 & - & 0.99 & - \\
\hline $3+$ & 0.99 & 0.99 & 0.96 & 0.94 & 0.96 & 0.94 & 0.99 & 0.75 \\
\hline
\end{tabular}

although that could not be determined in this study. The large genetic correlations between yields of records of treated and untreated cows suggest that rankings of sires from records of treated and untreated daughters would be similar. The impact of bST on genetic evaluations of dairy sires for milk yield traits and SCS will be examined in a later study by comparing EBV and rankings of sires with at least 3 different models: a model with bST treatment ignored, a model with bST treatment as a fixed effect, and a model with bST given or not given used to create contemporary groups.

\section{REFERENCES}

Albuquerque, L. G., J. F. Keown, and L. D. Van Vleck. 1996. Genetic parameters of milk, fat and protein yields in the first three lactations using an animal model and restricted maximum likelihood. Braz. J. Genet. 19:79-86.

Al-Jumaah, R. S. 2001. Influences of using bovine somatotropin on estimates of genetic parameters and genetic evaluation of dairy cows. PhD Dissertation, Univ. Nebraska, Lincoln.

Bauman, D. E. 1992. Bovine somatotropin: Review of an emerging animal technology. J. Dairy Sci. 75:3432-3451.

Bauman, D. E., P. J. Eppard, M. J. DeGeeter, and G. M. Lanza. 1985. Response of high producing dairy cows to long-term treatment with pituitary and recombinant somatotropin. J. Dairy Sci. 68:1352-1362.

Bauman, D. E., R. W. Everett, W. H. Weiland, and R. J. Collier. 1999. Production responses to bovine somatotropin in Northeast dairy herds. J. Dairy Sci. 82:2564-2573.

Boldman, K. G., L. A. Kriese, L. D. Van Vleck, C. P. Van Tassell, and S. D. Kachman. 1995. A Manual for Use of MTDFREML: A Set of Programs to Obtain Estimates of Variances and Covariances [Draft]. ARS, USDA, Washington, DC.

Burton, J. L., B. W. McBride, J. H. Burton, and R. G. Effert. 1990. Health and productive performance of dairy cows treated for up to 2 consecutive lactations with bovine somatotropin. J. Dairy Sci. 73:3258-3265.

Collier, R. J., J. C. Byatt, S. C. Denham, P. J. Eppard, A. C. Fabellar, R. L. Hintz, M. F. McGrath, C. L. McLaughlin, J. K. Shearer, J. J. Veenhuizen, and J. L. Vicini. 2001. Effects of sustained release bovine somatotropin (Sometribove) on animal health in commercial dairy herds. J. Dairy Sci. 84:1098-1108.

Da, Y., M. Grossman, I. Misztal, and G. R. Wiggans. 1992. Estimation of genetic parameters for somatic cell score in Holsteins. J. Dairy Sci. 75:2265-2271.

Dematawewa, C. M. B., and P. J. Berger. 1998. Genetic and phenotypic parameters for 305-day yield, fertility, and survival in Holsteins. J. Dairy Sci. 81:2700-2709.

Etherton, T. D., and D. E. Bauman. 1998. Biology of somatotropin in growth and lactation of domestic animals. Phys. Rev. 78:745-761.

Graser, H.-U., S. P. Smith, and B. Tier. 1987. A derivative-free approach for estimating variance components in animal models by restricted maximum likelihood. J. Anim. Sci. 64:1362-1370.

Hansen, W. P., D. E. Otterby, J. G. Linn, J. F. Anderson, and R. G. Eggert. 1994. Multi-farm use of bovine somatotropin for two consecutive lactations and its effects on lactational performance, health, and reproduction. J. Dairy Sci. 77:94-110.

Hartnell, G. F., S. E. Franson, D. E. Bauman, H. H. Head, J. T. Huber, R. C. Lamb, K. S. Madsen, W. J. Cole, and R. L. Hintz. 1991. Evaluation of sometribove in a prolonged system in lactating dairy cows-Production responses. J. Dairy Sci. 74:26452663.

Israel, C., and J. I. Weller. 2000. Effects of misidentification on genetic gain and estimation of breeding value in dairy cattle populations. J. Dairy Sci. 83:181-187.

Jordan, D. C., A. A. Aguilar, J. D. Olson, C. Bailey, G. F. Hartnell, and K. S. Madsen. 1991. Effects of recombinant methionyl bovine somatotropin (Sometribove) in high producing cows milked three times daily. J. Dairy Sci. 74:220-226.

Monsanto. 2006. POSILAC general information update. http:// www.monsantodairy.com/ updates/bovine.html Accessed March 8, 2006.

Peel, C. J., and D. E. Bauman. 1987. Somatotropin and lactation. J. Dairy Sci. 70:474-486.

Thomas, J. W., R. A. Erdman, D. M. Galton, R. C. Lamb, M. J. Arambel, J. D. Olson, S. Madsen, W. A. Samuels, C. J. Peel, and G. A. Green. 1991. Responses by lactating cows in commercial dairy herds to recombinant bovine somatotropin. J. Dairy Sci. 74:945-964.

Tsuruta, A., J. F. Keown, L. D. Van Vleck, and I. Misztal. 2000. Bias in genetic evaluations by records of cows treated with bovine somatotropin. J. Dairy Sci. 83:2650-2656.

Weigel, K. A., T. M. Fisher, C. Van Der Linde, D. Gianola, and R. Rekaya. 1998. Impact of bovine somatotropin on genetic evaluation of dairy sires and cows. J. Dairy Sci. 81:2045-2051. 